IJTC

Ilomata International Journal of Tax \& Accounting P-ISSN: 2714-9838; E-ISSN: 2714-9846

Vol. 1 No. 1 October 2019 page:18-25

https://www.ilomata.org/index.php/ijtc

\title{
Factors That Influence MSME Taxpayers' Willingness to Pay Tax After the Implementation of the Government Rules Number 23 of 2018
}

\author{
Ratih Kumala \\ Institute of Social and Management Studies STIAMI, Jakarta \\ Correspondence: rhaty07@gmail.com
}

Submitted: 6 August 2019.

18 Sept $2019 . \quad$ Published: 30 October 2019.

Revised: 24 August,

\begin{abstract}
Tax extensification and intensification are one of the government's way of improving tax revenue. Therefore, revenue officers are required to be active, as well as the taxpayers' awareness and willingness. The deficiency of willingness to pay taxes is inseparable from the lack of knowledge, understanding, service, and financial condition of taxpayers and is one of the factors that hinder taxpayer awareness in carrying out their tax obligations. This study aims to analyze the effect of tax awareness, knowledge and understanding of taxation rules, service quality, and financial conditions on the taxpayer readiness of individual income taxpayers. The population used in this study are the taxpayers of BOLU Online Business Community SMEs. The sample used was 100 respondents. The result of this study indicates that the awareness of paying taxes and the quality of service do not significantly influence the willingness to pay taxes. In contrast, knowledge and understanding of tax regulations and financial conditions have a positive influence on taxpayers' willingness to pay.

Keywords: tax awareness, knowledge and understanding of taxation rules, service quality, financial conditions, MSMEs, and GR No.23 of 2018
\end{abstract}

\section{INTRODUCTION}

Tax is the central source of internal revenue. Without taxation, the country is unable to develop well and smoothly. Most of the state revenue sources contained in the State Budget (APBN) come from taxes. This is evident in the realization of tax revenue in 2018, according to the revised state budget of 2018, the total tax revenue reached Rp.1, 315.9 trillion or grew by $14.3 \%$. This tax growth is the highest revenue since 2012 . The tax ratio also reached $11.5 \%$ of Gross Domestic Revenue (GDP), which increased by $0.8 \%$ from 2017 . With the improved tax revenue, the tax 
Factors That Influence MSME Taxpayers' Willingness to Pay Tax After the Implementation of the Government Rules Number 23 of 2018

Kumala

ratio experienced a significant improvement in just a year (https://www.kemenkeu.go.id).

To overcome these problems, the government through the Directorate General of Taxes since July 2013 issued Government Regulation (GR) No 46 of 2013 concerning tax regime from on business income of individual with a certain gross turnover was amended to Government Regulation (GR) No. 23 of 2018 which has been in effect since July 2018. Indirectly, the intended target of this Government Regulation is MSMEs, both individuals, and entities, except for permanent business entities that have gross circulation not more than Rp.4.8 billion.

Therefore, the writer wants to analyse the factors that influence the taxpayer's willingness to pay taxes after the enactment of Government Regulation No.23 of 2018 in the BOLU Online Business Community. The BOLU Community (Belajar Online Yuk!) is a community and place for online learning to maximize and develop its members' business. The BOLU community was established in 2014 and today has more than 3,000 members and alumni who have successfully developed their online business.

Based on Act 1 Number 16 of 2009, Tax is a mandatory contribution to a state owed by a personal or corporate taxpayer whose nature is coercive under the law by not getting a direct reward and is used for the country's needs for people's prosperity. Whereas according to Law article 1 Number 16 of 2009, the taxpayer is an individual or entity, including taxpayers, tax-cutters, and tax collectors, who have taxation rights and obligations per tax legislation's provisions.

In law Number 20, 2008, Article 1 in Chapter I, it is stated that microenterprise (MIE) is a productive business independently owned by a person or a business entity fulfilling the criteria of MIE. Small enterprise (SE) is a stand-alone productive economic enterprise undertaken by a person or a business entity that is not a subsidiary or not a branch of a medium enterprise (ME) or a large enterprise (LE) that meets the SE criteria. While medium enterprise is a stand-alone productive economic enterprise undertaken by a person or a business entity that is not a subsidiary or not a branch of a SE or a LE with the number of net assets or annual sales as stipulated in the Act. Last, large enterprise (LE) is a business owned by a business entity with a net worth or annual sales greater than a medium business.

Tax willingness is a value that is willing to be conditioned by someone (stipulated by the regulations) that is used to finance general state expenditures by not obtaining direct service (contra-performance) directly (Widayati and Nurlis, 2010). 
Factors That Influence MSME Taxpayers' Willingness to Pay Tax After the Implementation of the Government Rules Number 23 of 2018

Kumala

Tax awareness can be interpreted as a form of moral attitude by providing a contribution to the state to support the country's development and seeks to comply with all regulations that have been set by the state that can be forced on taxpayers. The important indicators in raising awareness among taxpayers are by creating taxpayers' positive perceptions about their tax obligations, studying the characteristics of taxpayers, increasing taxpayers' knowledge of taxation, and apprising taxation to taxpayers (Suryadi, 2006).

Tax knowledge is the process of changing an individual or group of taxpayers' attitudes and behavior in hopes of maturing humans through teaching and training efforts. Public's knowledge of tax regulations through formal and non-formal education will have a positive impact on taxpayer awareness to pay taxes, such as counseling or tax socialization. Meanwhile, taxpayers' understanding of taxation regulations is a way for taxpayers to understand existing taxation regulations. Taxpayers who are unable to understand tax regulations tend to be disobedient. The more taxpayers understand the tax regulations, the more aware they are of the sanctions they would receive if they neglect their tax obligations. If the taxpayers truly understand, they would know about tax returns and taxpayer identification number's administrative and criminal sanctions.

Excellent service is one of the factors in creating customer satisfaction. A service is said to be good if the business is running as expected. Service quality is a service that can provide satisfaction to customers but remains within the limits of service standards that can be accounted for and must be carried out continuously (Hardiningsih, 2011). When the taxpayers are satisfied with the services provided, then they will tend to pay taxes obligation according to the regulations applied. If the tax provisions are simple and easily understood by the taxpayers, the taxation services on their rights and obligations can be effective and efficient. Thus, the taxation information system and reliable human resources quality will result in better taxation services.

A person's financial condition may positively or negatively affect their willingness to meet their tax provisions regardless of the taxpayer's perception of tax services' quality and compliance behaviour. Someone who is experiencing financial difficulties would feel depressed when they are required to pay their obligations including taxes (Torgler, 2003). Blomquist (2003) identified that financial pressure as a source of pressure for taxpayers and believes that individual taxpayers who have limited income might avoid paying taxes if their financial condition is severe because the family's expenditure is greater than income. This shows that regardless of the relationship between tax services' quality perception and compliance behaviour, tax obligations compliance depends among other things, such as the individual's financial condition. 
Factors That Influence MSME Taxpayers' Willingness to Pay Tax After the Implementation of the Government Rules Number 23 of 2018

Kumala

\section{METHOD}

This research used primary data in the form of a questionnaire filled out by the respondents. Primary data sources in this study were given directly to the respondents. The population in the research is the MSMEs of BOLU Online Business Community and 100 taxpayer respondents' samples are taken.

From the total population obtained, this study will take a sample using the Simple Random Sampling technique, because of the ease in obtaining the data needed.

For the data collection techniques in this research, the authors collected data through the distribution of questionnaires to MSMEs Taxpayers with the measurement method used to measure respondents' opinions is the 5-point Likert scale.

The conceptual framework illustrated to explain the thought process in the research is:

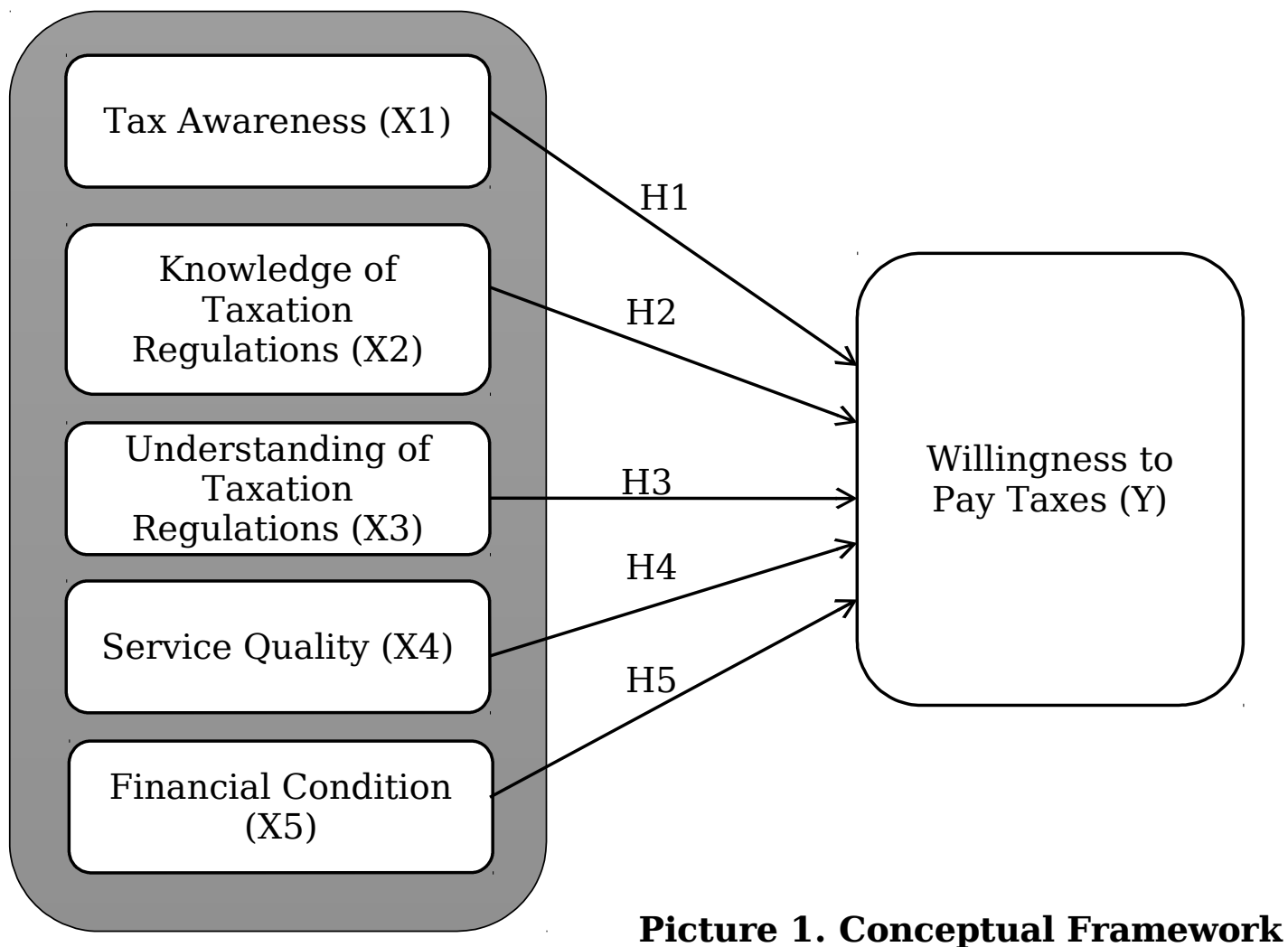

Based on the picture above, the problem that will be addressed in this research is the taxpayer's high understanding of tax regulations that come from taxpayers compliance, then the taxpayers' compliance will be high and the state income from taxes will increase, so the hypothesis in this study is:

H1: Tax Awareness affects Willingness to Pay Taxes.

$\mathrm{H} 2$ : Knowledge of Tax Regulations influences Willingness to Pay Taxes.

H3: Understanding of Tax Regulations affect Willingness to Pay Taxes. 
Factors That Influence MSME Taxpayers' Willingness to Pay Tax After the Implementation of the Government Rules Number 23 of 2018

Kumala

$\mathrm{H}_{4}$ : Service Quality affects Willingness to Pay Taxes.

$\mathrm{H}_{5}$ : Financial conditions influence Willingness to Pay Taxes.

\section{RESULT AND DISCUSSION}

Table 1. Regression Coefficient Results

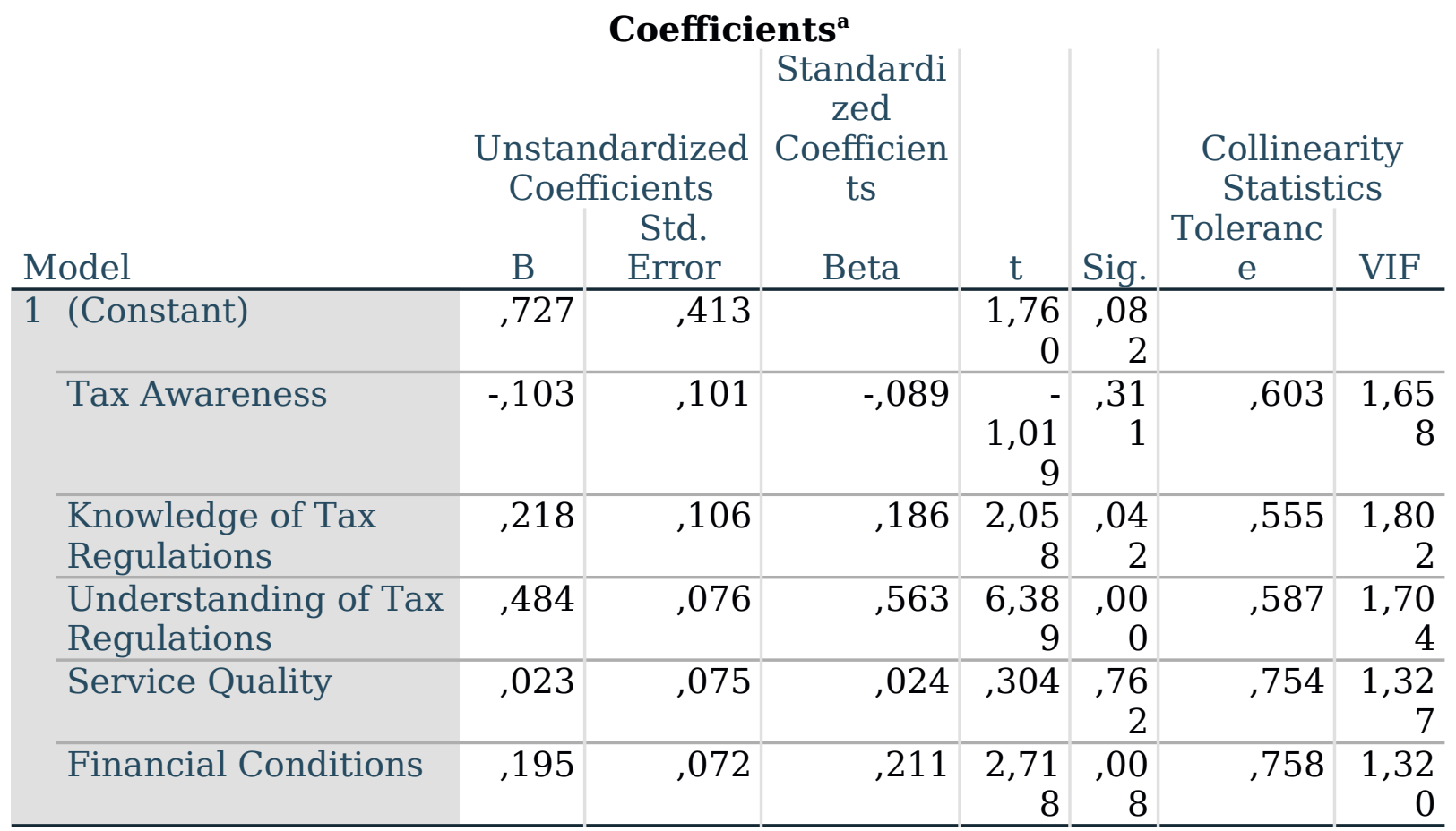

$\overline{\text { a. Dependent Variable: Willingness to Pay }} \overline{\text { Taxes }}$

The table above is the coefficient result of the regression equation, thus to obtain the regression equation from the results of this research are as follows:

$$
Y=0,727-0,103 X_{1}+0,218 X_{2}+0,484 X_{3}+0,023 X_{4}+0,195 X_{5}
$$

Based on the results of the regression equation, the multiple linear regression equation has a meaning, scilicet:

The constant value is 0.727 and has a positive sign indicating that if the five independent variables (awareness of paying taxes, knowledge of tax regulations, understanding of tax regulations, quality of tax services, and financial conditions) value is zero, then the value of paying tax remains fixed at $0.727 \%$.

The regression coefficient value of tax awareness 0.103 and is negative, indicating that tax awareness is not aligned with the willingness to pay MSMEs taxes. This implies that for every $1 \%$ decrease in tax awareness, the willingness to pay taxes will decrease by $0.103 \%$ if the other independent variables of the regression model remain.

The regression coefficient value of tax knowledge understanding 0.218 and positive, indicating that the knowledge of tax regulations has a 
Factors That Influence MSME Taxpayers' Willingness to Pay Tax After the Implementation of the Government Rules Number 23 of 2018

Kumala

direct relationship with the willingness to pay MSMEs taxes. This implies that every $1 \%$ increase in knowledge of tax regulations, the willingness to pay taxes will increase by $0.218 \%$ if the other independent variables of the regression model remain.

The regression coefficient value of understanding of tax regulations is 0.484 and has a positive sign, which indicates that understanding tax regulations has a direct relationship with the willingness to pay MSMEs taxes. This implies that every $1 \%$ increase in understanding of tax regulations, the willingness to pay taxes will increase by $0.484 \%$ if the other independent variables of the regression model remain.

The regression coefficient value of tax service quality is 0.023 and positive, indicating that the quality of tax services has a direct relationship with the willingness to pay MSMEs taxes. This implies that for every $1 \%$ of the quality of tax services, the willingness to pay taxes will increase by $0.023 \%$ if the other independent variables of the regression model remain.

The regression coefficient value of the taxpayer's financial condition is 0.195 and positive, indicating that the taxpayer's financial condition has a direct relationship to the willingness to pay MSMEs taxes. This implies that for every $1 \%$ of the taxpayer's financial condition, the willingness to pay taxes will increase by $0.195 \%$ if the other independent variables of the regression model remain.

\section{Significant Simultaneous Test Result (F-Test)}

If the $\mathrm{F}$ value $>\mathrm{F}$ statistic, then $\mathrm{H}_{\mathrm{O}}$ is rejected and $\mathrm{H}_{\mathrm{A}}$ is accepted, and if the significant value is $<0.05$, then the independent variables together have a significant effect on the dependent variables (Ghozali, 2016).

\section{Table 2. F-Test Result}

\begin{tabular}{|c|c|c|c|c|c|c|}
\hline \multicolumn{7}{|c|}{ ANOVA $^{a}$} \\
\hline \multicolumn{2}{|c|}{ Model } & $\begin{array}{l}\text { Sum of } \\
\text { Squares }\end{array}$ & Df & $\begin{array}{l}\text { Mean } \\
\text { Square }\end{array}$ & $\mathrm{F}$ & Sig. \\
\hline \multirow[t]{3}{*}{1} & $\begin{array}{l}\text { Regressio } \\
n\end{array}$ & 13,736 & 5 & 2,747 & 25,142 &, $000^{\mathrm{b}}$ \\
\hline & Residual & 10,271 & 94 & 109 & & \\
\hline & Total & 24,007 & 99 & & & \\
\hline
\end{tabular}

a. Dependent Variable: Willingness to Pay Taxes

b. Predictors: (Constant), Financial Conditions, Service Quality, Tax

Awareness, Understanding of Tax Regulations, Knowledge of Tax

Regulations

Source: Data processed by SPSS 25, 2019

Based on the F-Test Result Table above, it can be acquired that the value of the $F_{\text {value }}>F_{\text {statistic }}$ is $25.142>2.31$ and significant value of $0.000<$ 0.05. Thus from this value, it can be concluded that tax awareness, knowledge of tax regulations, understanding of tax regulations, service quality, and financial conditions have a significant effect on the willingness 
Factors That Influence MSME Taxpayers' Willingness to Pay Tax After the Implementation of the Government Rules Number 23 of 2018

Kumala

to pay MSME taxes.

\section{Partial Test Result (T-Test)}

If the significance level on the table is $1>0,05$, the $\mathrm{T}$ calculated value $<\mathrm{T}$ statistic then $\mathrm{H}_{\mathrm{A}}$ would be accepted and $\mathrm{H}_{\mathrm{O}}$ would be rejected, then there is no no influence between the independent variables and the dependent variables (Ghozali, 2016). From the table can be concluded as follow:

Tax awareness has a negative effect on MSME's willingness to pay taxes. This is indicated by the level of significance value of $0.311>0.05$, and the $t_{\text {value }}$ of $-1.109<1.660$. Meaning, tax awareness has a negative effect or does not have a significant effect on the willingness to pay MSME taxes.

Knowledge of tax regulations has a positive effect on MSMEs' willingness to pay taxes. This is indicated by the level of significance value $0.042<0.05$, and $t_{\text {value }}$ is greater than the $t_{\text {statistic }}$ of $2.058>1.660$. That is, knowledge of tax regulations has a significant effect on the willingness to pay MSME taxes.

Understanding tax regulations have a negative effect on MSMEs' willingness to pay taxes, indicated by the level of significance value of $0,000<0.05$, and the $t_{\text {value }}$ of $6.389>1.660$. That is, understanding tax regulations has a significant effect on MSMEs' willingness to pay taxes.

Service quality has a negative effect on MSMEs' willingness to pay taxes. This is shown by the level of significance value $0.762>0.05$, and the $t_{\text {value }}$ is greater than the value of $t_{\text {statistic }}$ by $0.304<1.660$, which means the quality of tax services does not significantly influence the willingness to pay MSME taxes.

The financial condition of the taxpayer has a positive effect on the willingness to pay tax on MSMEs. This is indicated by the level of significance value $0.008<0.05$, and the $t_{\text {value }}$ is greater than the $t_{\text {statistic }}$ of $2.718>1.660$, which means the taxpayer's financial condition has a significant effect on the willingness to pay MSME taxes.

\section{Coefficient of Determination Test $\left(\mathbf{R}^{2}\right)$}

The coefficient of determination $\left(\mathrm{R}^{2}\right)$ measures how far does the model able to explain the dependent variables (Ghozali, 2016).

\section{Table 3. Coefficient of Determination Test Result $\left(\mathbf{R}^{2}\right)$}

\begin{tabular}{|c|c|c|c|c|}
\hline \multicolumn{5}{|c|}{ Model Summary } \\
\hline $\begin{array}{l}\text { Mode } \\
1\end{array}$ & $\mathrm{R}$ & $\begin{array}{c}\mathrm{R} \\
\text { Square } \\
\end{array}$ & $\begin{array}{l}\text { Adjusted R } \\
\text { Square }\end{array}$ & $\begin{array}{l}\text { Std. Error } \\
\text { of the } \\
\text { Estimate }\end{array}$ \\
\hline 1 &, $756^{\mathrm{a}}$ & ,572 &, 549 & ,33056 \\
\hline $\begin{array}{l}\text { a. Pre } \\
\text { Servi } \\
\text { Tax R }\end{array}$ & $\begin{array}{l}\text { dality } \\
\text { ation }\end{array}$ & Knowlec & $\begin{array}{l}\text { eness, Unde } \\
\text { ge of Tax Re }\end{array}$ & $\begin{array}{l}\text { ditions, } \\
\text { tanding of } \\
\text { ulations }\end{array}$ \\
\hline
\end{tabular}


Factors That Influence MSME Taxpayers' Willingness to Pay Tax After the Implementation of the Government Rules Number 23 of 2018

Kumala

From the table above, the coefficient of determination (R2) measures how far does the model able to explain the dependent variables (Ghozali, 2016). The coefficient of determination $\mathrm{R}^{2}$ is obtained by 0.572 or $(57.2 \%)$. This shows that the independent variables (tax awareness, knowledge of tax regulations, understanding of tax regulations, service quality, and financial conditions) can explain the effect of the dependent variables (willingness to pay MSMEs taxes) by $57.2 \%$ and the remaining $42.8 \%$ is influenced by other variables not included in this study.

\section{Tax Awareness towards the Willingness to Pay MSME Taxes}

The results of this study indicate that tax awareness does not significantly influence the willingness to pay taxes for MSMEs. Meaning that taxpayers do not understand their tax rights and obligations. However, this research is contrary to Permana's study (2015) which stated that taxpayer awareness has a significant effect on the willingness to pay taxes and the results of Sari's research (2017) that stated the same thing.

\section{Knowledge of Taxation Regulations towards the Willingness to Pay MSME Taxes}

The results of this study show that the knowledge of tax regulations has a significant effect on the willingness to pay MSME taxes. This means that if taxation knowledge is increasingly known among taxpayers, the willingness to pay taxes would also increase. The results of this study are in accordance with Sari (2017) knowledge of tax regulations has a significant effect on the willingness to pay taxes. But this study is in contrast with Permana's finding (2015) that knowledge of taxation regulations does not significantly influence the willingness to pay taxes.

\section{Understanding of Taxation Regulations towards the Willingness to Pay MSME Taxes}

The results of this study reveal that understanding taxation regulations has a significant effect on the willingness to pay MSME taxes. Meaning that if the understanding of tax regulations is increasingly understood by taxpayers, the willingness to pay taxes would also increase. The results of this study are compatible with Sari (2017) knowledge of tax regulations has a significant effect on the willingness to pay taxes. In contrast, Permana (2015) stated that knowledge of taxation regulations does not significantly influence the willingness to pay taxes.

\section{Service Quality towards the Willingness to Pay MSME Taxes}

The results of this study indicate that the service quality does not significantly influence the willingness to pay MSME taxes. This proves that taxpayers have not experienced adequate services yet so there is no 
Factors That Influence MSME Taxpayers' Willingness to Pay Tax After the Implementation of the Government Rules Number 23 of 2018

Kumala

willingness to pay taxes. The results of this study are in harmony with Sari's research (2017) which stated that the quality of tax services does not significantly influence the willingness to pay taxes. Whereas both Pancawati (2011) and Permana's (2015) research stated that the quality of services significantly positively affects the willingness to pay taxes.

\section{Financial Conditions towards the Willingness to Pay MSME Taxes}

The outcome of this study reveals that financial conditions significantly influence the willingness to pay taxes. This confirms that the taxpayer's financial condition influences their willingness to fulfill their tax obligations. Likewise, the study of Sulastri et al (2016) and Fitri's research (2017) also stated that financial conditions significantly influence the willingness to pay taxes.

\section{CONCLUSION}

Tax awareness does not significantly affects the willingness to pay MSME Taxes. This shows that taxpayers do not understand their tax rights and obligations yet.

The knowledge of tax regulations has a significant effect on the willingness to pay MSME taxes. This means that if taxation knowledge is increasingly known among taxpayers, the willingness to pay taxes would also increase.

Understanding of taxation regulations has a significant effect on the willingness to pay MSME taxes. Meaning that if the understanding of tax regulations is increasingly understood by taxpayers, the willingness to pay taxes would also increase.

Service quality does not significantly influence the willingness to pay MSME taxes. This proves that taxpayers have not experienced adequate services yet so there is no willingness to pay taxes.

Financial conditions significantly influence the willingness to pay taxes. This confirms that the taxpayer's financial condition influences their willingness to fulfill their tax obligations.

REFERENCEXBlomquist, John. 2003. Impact Evaluation of Social Programs: A Policy Perspective. Social Safety Nets Primer Paper, World Bank. Washington, D.C.

Ghozali, Imam. 2016. Aplikasi analisis Multivariative dengan Program SPSS. Badan Penerbit Universitas Diponegoro: Semarang.

Hardiningsih, Pancawati. 2011. Faktor-Faktor Yang Mempengaruhi Membayar Pajak. Jurnal Dinamika Keuangan dan Perbankan, Nopember 2011, Hal: 126-142. ISSN : 1979-4878. 
Factors That Influence MSME Taxpayers' Willingness to Pay Tax After the Implementation of the Government Rules Number 23 of 2018

Kumala

Peraturan Pemerintah. Nomor 46 Tahun 2013. Direktorat Jendral Pajak. Tentang PPh Atas Penghasilan Dari Usaha Wajib Pajak Yang Memiliki Peredaran Bruto Tertentu.

Peraturan Pemerintah. Nomor 23 Tahun 2018. Direktorat Jendral Pajak. Tentang PPh Atas Penghasilan Dari Usaha Wajib Pajak Yang Memiliki Peredaran Bruto Tertentu.

Permana, C.A. 2015. Faktor-Faktor Yang Mempengaruhi Kemauan Wajib Pajak Pelaku UMKM Untuk Membayar Pajak Setelah Diberlakukan PP No.46 Tahun 2013 (Survei Pada Wajib Pajak Yang Terdaftar di KPP Pratama Surakarta).

Sari, Fitria. 2017. Pengaruh Kesadaran Membayar Pajak, Pengetahuan dan Pemahaman Peraturan Perpajakan, Kualitas Layanan, dan Kondisi Keuangan Terhadap Kemauan Membayar Pajak Wajib Pajak Orang Pribadi. Skripsi Fakultas Ekonomi dan Bisnis Universitas Muhammadiyah Surakarta.

Sulastri, Ita Dewi, dkk. 2016. Pengaruh Presepsi Pengetahuan Pajak, Sistem Perpajakan, Kesadaran Membayar Pajak dan Kondisi Keuangan Terhadap Kemauan Membayar Pajak Penghasilan Pada Wajib Pajak. Ejournal.unisri.ac.id Volume 12 No.2.

Torgler, B. (2003a). Cross Culture Comparison of Tax Morale and Tax Compliance: Evidence from Costa Rica and Switzerland, WWZ Discussion Paper, University of Basel.

Torgler, B. (2003). Tax Morale, Rule-Governed Behaviour and Trust, Constitutional Political Economy, Vol. 14 No. 2 pp. 119-140.

Undang-undang Republik Indonesia Nomor 16 Tahun 2009 Tentang Perubahan Keempat Atas Undang-undang Nomor 6 Tahun 1983 Tentang Ketentuan Umum dan Tata Cara Perpajakan.

Undang-Undang Republik Indonesia Nomor 20 Tahun 2008 tentang Usaha Mikro Kecil Menengah.

Widaningrum, Dwi Indah. (2007). “Identifikasi Kemampuan dan Kemauan Membayar Masyarakat Berpenghasilan Menengah rendah (Di Lokasi Rencana Pembangunan Rumah Susun Tamansari Kota Bandung)". Tugas Akhir. Diambil dari: www.sappk.itb.ac.id (diambil pada 11 september 2016)

Widayati. dan Nurlis. 2010. "Faktor-Faktor Yang Mempengaruhi 
Factors That Influence MSME Taxpayers' Willingness to Pay Tax After the Implementation of the Government Rules Number 23 of 2018

Kumala

Kemauan Untuk Membayar Pajak Wajib Pajak Orang Pribadi Yang Melakukan Pekerjaan Bebas (Studi Kasus Pada Kpp Pratama Gambir Tiga).” Makalah Simposium Nasional Akuntansi XIII. Purwokerto.

https://www.kemenkeu.go.id/publikasi/berita/ini-capaian-apbn-2018/ 